\title{
Isolation and identification of protease-producing bacteria from sludge and sediment soil around Adama, Ethiopia
}

\author{
Yeshaneh Adimasu Lemenh ${ }^{1,}{ }^{*}$, Teshome Geremew Biru ${ }^{1}$, Adinew Zewdu Chernet ${ }^{2}$ and Feleke Belachew Lema ${ }^{2}$ \\ ${ }^{1}$ Department of Applied Biology, School of Applied Natural Science, Adama Science and Technology University (ASTU), Adama, Ethiopia \\ ${ }^{2}$ Oromia Public Health Research Capacity Building and Quality Assurance Laboratory (OPHRCBQAL), Adama, Ethiopia \\ ${ }^{*}$ Corresponding author: yeshu0192@gmail.com
}

SUBMITTED 29 February 2021 REVISED 12 May 2021 ACCEPTED 10 June 2021

\begin{abstract}
Proteases are enzymes used in industries such the production and processing of detergents, food, leather, and silk. The aim of this study was to isolate and identify protease-producing bacteria from a sludge disposal site and from sediments. Soil samples were collected separately from the selected area. Samples weighing $1 \mathrm{~g}$ were serially diluted and spread onto skim milk agar. A total of 16 bacteria species were isolated from the study samples. Four bacterial isolates showed high proteolytic activity and were selected for enzymatic study based on their zone of proteolysis. The isolates were identified based on biochemical tests. The results indicated that the isolated bacteria were E. coli (99.69\%), Pseudomonas putrefaciens (Shewanella putrefaciens) (91.61\%), Bacillus carboniphilus (92.78\%), and Lysinibacillus sphaericus (98.4\%). The crude protease enzymes produced by these bacterial isolates showed promising results for application in dehairing and destaining as detergent additives. Bacillus carboniphilus showed the best level of activity and was selected as the most potent protease-producing bacteria for both dehairing and destaining ability. Soils from sludge disposal sites and sediments from around tannery wastes could be good sources from which to isolate alkaline protease-producing bacteria.
\end{abstract}

KEYWORDS Alkaline protease; dehairing; destaining; hydrolysis; sediment

\section{Introduction}

Microbes are a preferred source of enzymes than plants and animals due to their short generation time, cultivating in small space, and making it easy for genetically manipulated to generate new enzymes for various applications ranging from domestic to industrial processes. Examples of industrial processes include leather processing, food, chemical, environmental pollution abatement, diagnostic kits development for clinical applications (Kocher and Mishra 2010).

There is a huge demand for protease enzymes imported for use in leather tanning, textile, and brewing industries. Alkaline protease has attracted worldwide attention to achieve its physiological and biotechnological applications due to diversity and the specificity of action. Isolation and characterization of new bacteria strains are the best ways to increase the diversity and yield of such enzymes. Even if the same species of protease-producing microbes, especially bacteria, are isolated from different environments, their effectiveness is completely different. High amounts of protein waste from plants and animals are released annually; one such protein waste is keratin released from leather tanning industries in the form of hair. Over $90 \%$ of keratins are protein, and are highly crystalline and cannot be digested by most enzymes. But some microorganisms can hydrolyze keratin (Gupta et al. 2002).

Therefore, bioprospecting for new microorganisms that can be used for protease production is a necessary continuous process for industrial development and environmental conservation. Since, most industrial microbes are patented and/or must be purchased for use outside their country of origin, isolation of bacterial strains are good ways to increase the diversity and yield of such enzymes (Gupta et al. 2002). Alkaline protease-producing bacteria isolated from different environments may have different potential in their enzyme's effectiveness. Hence, the use of microbial enzymes for industrial processes has offered a viable option to decrease environmental pollution and leads to improved product quality or process efficiency microbes (Gupta et al. 2002; Kocher and Mishra 2010).

Ethiopia is on rapid expansion of various industries, like textile, leather, detergent, pulp and paper, food and dietary industry. Some of these industries highly depend on chemical utilizations, which leads to environmental pollution (Gessesse et al. 2011). According to this report, the market for proteases enzymes in the East African region (Ethiopia and Tanzania alone) was estimated to US\$ 3.8 million per annum. The massive move to industrialize 
the country created a demand gap for the enzyme, especially protease. This needs the isolation of suitable microorganisms from within the country for sustainable utilization in the rapidly growing Ethiopian industrial sector, which could replace several imported chemicals as processing aids and encourage local industries to adopt enzyme technology. Therefore, the objective of this study was to isolate and identify alkaline protease-producing bacteria from sludge disposal sites and sediment located in central Ethiopia.

\section{Materials and Methods}

\subsection{Study area}

Adama is a city in central Ethiopia. It is located at $8.54^{\circ}$ $\mathrm{N} 39.27^{\circ} \mathrm{E}$ at the elevation of $1712 \mathrm{~m}$ above sea level (m.a.s.l) and $99 \mathrm{~km}$ southeast of Addis Ababa. Modjo Tannery Share Company is located around Adama city. Modjo is a small town named after the nearby Modjo River. Modjo is located in the East Shewa Zone of the Oromia region. It has a latitude ( $\left.8^{\circ} 35,12.44 ” \mathrm{~N}\right)$ and longitude $\left(39^{\circ} 07^{\prime} 16.00\right.$ ” E) and with an elevation between 1788 and 1825 m.a.s.l.

\subsection{Sample collection}

Five hundred grams (g) of soil samples were collected from the sludge disposal site of Adama Science and Technology University campus and sediments from Modjo Tannery Share Company with a sterile spatula from 5 cm depth into sterile plastic bags. The samples were labeled with site name, date of sample collection, and sample type and transported to Oromia Public Health Research Capacity Building and Quality Assurance Laboratory (OPHRCBQAL) at the bacteriology laboratory. The samples were air-dried at room temperature for a week and maintained at room temperature for further analysis.

\subsection{Isolation of protease producing bacteria}

Isolation of bacteria was carried out with serial dilution techniques and the spread plate method (Sneath 1986). One-gram soil samples (sediment and sludge) were aseptically sub-sampled from 500 g samples after thorough mixing and then transferred to $9 \mathrm{~mL}$ ) distilled water and serial diluted up to 10-6 (i.e., 10-1-10-6). Serially diluted aliquot $1 \mathrm{~mL}$ was spread on skim milk agar. The plates were incubated at $37^{\circ} \mathrm{C}$ for $48 \mathrm{~h}$. Moreover, zones of hydrolysis were recorded. The colonies showing the highest clearance zone were selected for further study and repeatedly purified on nutrient agar plates and preserved at room temperature.

\subsection{Identification and Characterization of protease producing bacteria}

\subsubsection{Morphological characterization}

The bacterial cultures grown on blood agar were characterized based on colony morphology like colony type, shape, margin, and elevation with reference to Bergey's manual of determinative bacteriology 7ed.

\subsubsection{Microscopic characterization}

Microscopic examination was carried out from slide preparations and Gram staining methods to distinguish the isolated strains as Gram-positive or Gram-negative bacteria. Every single colony from $24 \mathrm{~h}$ incubation was purified. Old culture on agar plate was taken with loop, put on the center of the clean slide, and made to smear. The smear was fixed on the slide with heat and stained with crystal violet for one minute. Then iodine was added, waited for one minute, and two drops of alcohol were added as a decolorizing agent.

Finally, a counterstain, safranin, was added and rinsed with water after one minute. The slide preparation was viewed under a microscope using oil emulsion objective $1000 \times$ magnification power. The result was recorded as Gram-positive (purple) and Gram-negative bacteria (pink color) (Murray et al. 2007).

\subsubsection{Enzyme tests}

Catalase test. Three drops of $3 \%$ of $\mathrm{H}_{2} \mathrm{O}_{2}$ solution were added to bacteria cultures grown on a nutrient broth medium. The bubble formation was indicated as a positive reaction, while no bubble formation was considered a negative reaction for the catalase test (Nikolic et al. 2008).

Oxidase test. Oxidase test was conducted following the method described in (Nikolic et al. 2008). One drop of $1 \%$ p-amino dimethylaniline oxalate (Gaby and Hadley reagents) was flooded on bacteria culture on oxidase strip paper. The color was changed to deep purple-blue/blue color within $30 \mathrm{~s}$ as positive results.

Urease test. The urea hydrolysis test was conducted according to the method described by (Nikolic et al. 2008). A loopful of bacterial culture was inoculated into a test tube containing urea broth and then incubated for $24 \mathrm{~h}$. at $37^{\circ} \mathrm{C}$. The development of bright pink color was indicative of a positive result for urea hydrolysis.

\subsubsection{Biochemical test}

The biochemical characterization of bacteria cultures that grow on nutrient agar and/or nutrient broth was carried out using both commercial kits (Biomerieux API kits) and manual methods. The preparation of bacteria suspension and setting up of API strips were done based on the procedure of Global Health Network Laboratory (Microbiology Standard Operating Procedure). The biochemical tests include catalase, oxidase, indole production, citrate utilization, carbohydrate fermentation, urease, hydrogen sulfide production, and nitrate reduction test. Colonies of bacteria culture were taken from blood agar and then transferred into $5 \mathrm{~mL}$ of saline solution. The bottom tray of the API kite strips holder was filled with distilled water. The API strips were elevated at an angle of $30^{\circ}$, then $50 \mu \mathrm{L}$ of bacterial suspension were added on one side of the tube by 
touching the inside wall of the cupule with the end of the pipette. Each of the tubes on the API strips was filled with the bacteria suspension from left to right. Next, mineral oil was added on the top of the cupule area of tubes containing dehydrated substances (ADH, LDC, ODC, H2S, Urea, and glucose) and incubated at $37^{\circ} \mathrm{C}$ for $24 \mathrm{~h}$.

\subsection{Enzymatic study}

\subsubsection{Crude enzyme extraction}

Loop full of protease producing bacterial culture from broth was inoculated into a test tube containing $30 \mathrm{~mL}$ of sterilized skim milk broth (pH. 9.0) and incubated at $37^{\circ} \mathrm{C}$ for $48 \mathrm{~h}$. After incubation period the cultures were centrifuged at 10,000 rpm for $10 \mathrm{~min}$. The supernatant was separated from residues and used as crude enzyme for enzymatic activity (Aftab et al. 2006).

\subsubsection{Washing test}

Application of alkaline protease enzyme by isolated bacteria as a detergent additive was studied according to a method described by (Aftab et al. 2006). For these six white cotton clothes $5 \times 5 \mathrm{~cm}$ were stained with sheep blood separately and then waited until it becomes well dried. The following setups were designed to test the enzymatic activity of supernatant to washing tests. A bloodstained cloth dipped in a plate with distilled water $(10 \mathrm{~mL})$. Blood-stained cloth dipped in plate with distilled water (10 $\mathrm{mL})+(1 \mathrm{~mL})$ detergent $(7 \mathrm{mg} / \mathrm{mL})$. Blood-stained cloth dipped in a plate with distilled water $(10 \mathrm{~mL})+(2 \mathrm{~mL})$ crude enzyme solution (supernatant of APBIT-3, APBIS4, APBIT-6, and APBIT-6) in a separate plate. All plates were incubated at $40{ }^{\circ} \mathrm{C}$ for $20 \mathrm{~min}$. After incubation, cloths were taken out and were rinsed with distilled water without scrubbing and then dried. Where APBIT= alkaline protease producing bacteria from sediment soil and APBIS= alkaline protease producing bacteria from sludge soil.

\subsubsection{Dehairing activity}

Dehairing activity was performed by the method described by (Dudhgara et al. 2015). Sheepskin was cut $3 \times 2 \mathrm{~cm}$ pieces and washed gently with tap water and then rinsed with distilled water to remove chemicals from the skin, which may hinder enzyme activity during dehairing activity. Four $(3 \times 2 \mathrm{~cm})$ pieces of skins were inserted into $15 \mathrm{~mL}$ ) tubes separately. Five milliliters $(5 \mathrm{~mL})$ of crude enzyme solution (supernatant of APBIT-3, APBIS4, APBIT-6, and APBIT-7) were added sequentially and incubated at $40^{\circ} \mathrm{C}$ for $48 \mathrm{~h}$. After incubation, the skin was taken out and peel with a swab stick and then observed the dehairing ability of the crude enzymes.

\subsection{Data analysis}

The experiment was performed in triplicate and the data were analyzed and interpreted using Microsoft Excel
2013. Using Bergey’s Manual of Determinative Bacteriology 7ed. Furthermore, ABIS version 12 online software was used for the identification of bacterial species.

\section{Results and Discussion}

\subsection{Screening of protease producing bacteria}

A total of 16 bacterial isolates showing zone of proteolysis were obtained in this study on skim milk agar plates inoculated with the soil samples, as shown in Table 1. Among the sixteen isolates obtained through screening by growing on skim milk agar, four bacterial cultures were selected, which showed zones of hydrolysis $\geq 25 \mathrm{~mm}$. From these, APBIS-4 from the soil of sludge disposal site at Adama Science and Technology University (ASTU) campus and APBIT-3, APBIT-6 and APBIT-7 from sediment soil collected from Modjo Tannery Share Company (MTSC) showed a promising zone of hydrolysis $(\geq 25$ $\mathrm{mm}$ ). These four isolates were subsequently selected for further study.

In this finding, four potential alkaline proteaseproducing bacterial isolates obtained from sludge disposal site and tannery waste showed promising proteolytic activity on skim milk agar. This implies that sludge disposal sites and soil sediment around tannery waste are good protease-producing bacteria sources. The potential of sludge disposal site soils in ASTU Campus and sediment at Modjo Tannery Share Company waste has not been reported as a source of alkaline protease-producing bacteria so far. Hence the need to search for potential protease producing bacteria in unexploited sites such as sediments and sludge disposal sites for commercially ex-

TABLE 1 Zone of hydrolysis of isolated bacteria on skim milk agar.

\begin{tabular}{|c|c|c|}
\hline Sample sources & Isolates & Zone of hydrolysis/mm \\
\hline \multirow{7}{*}{ Sludge sample } & APBIS-1 & 13 \\
\hline & APBIS-2 & 20 \\
\hline & APBIS-3 & 16 \\
\hline & APBIS-4 & 36 (selected) \\
\hline & APBIS-5 & 17 \\
\hline & APBIS-6 & 12 \\
\hline & APBIS-7 & 6 \\
\hline \multirow{10}{*}{ Sediment soil } & APBIS-8 & 5 \\
\hline & APBIT-1 & 19 \\
\hline & APBIT-2 & 14 \\
\hline & APBIT-3 & 55 (selected) \\
\hline & APBIT-4 & 12 \\
\hline & APBIT-5 & 20 \\
\hline & APBIT-6 & 29 (selected) \\
\hline & APBIT-7 & 32 (selected) \\
\hline & APBIT-8 & 15 \\
\hline & Total & 16 \\
\hline
\end{tabular}

APBIS= alkaline protease producing bacteria from sludge soil $\mathrm{APBIT}=$ alkaline protease producing bacteria from sediment soil 
ploitable species of bacteria.

\subsection{Cultural characterization bacteria isolated from sediment}

Table 2. shows that the selected bacteria isolate (APBIT3, PBIS-4, APBIT-6 and APBIT-7) showed different morphological characteristics (colony type, shape, texture, elevation, margin and pigmentation or color) as described in Figure 1.

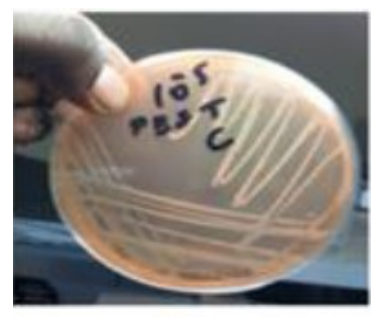

APBIT-3

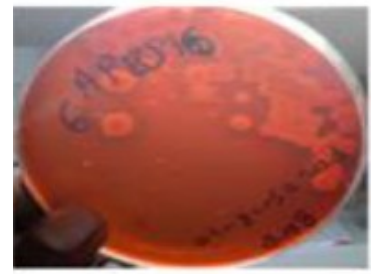

APBIT-6

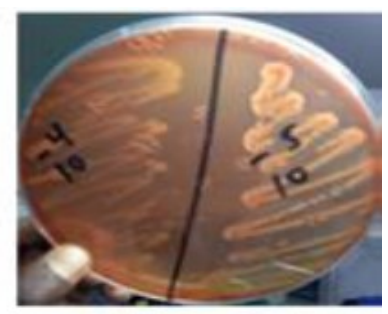

APBS-4 (left)

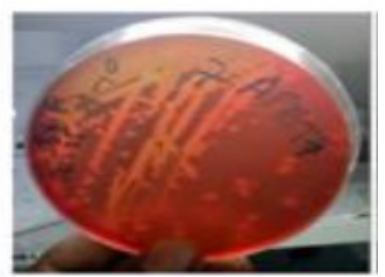

APBIT-7
FIGURE 1 Morphologies of isolated colonies.

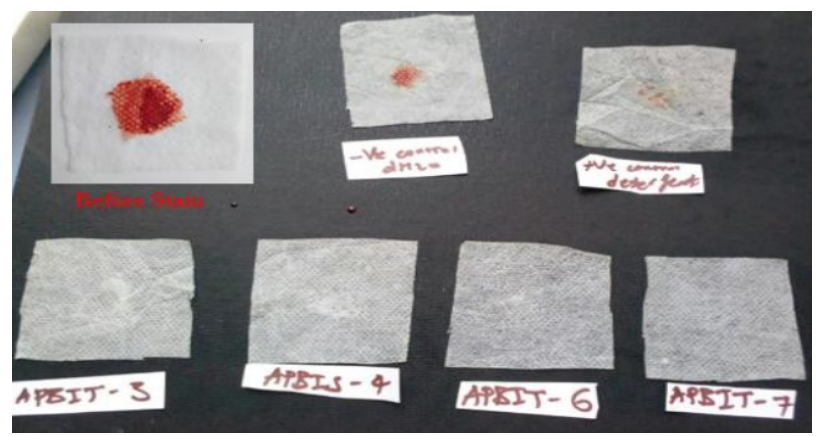

FIGURE 2 Washing abilities of crude enzymes extracted from bacteria.
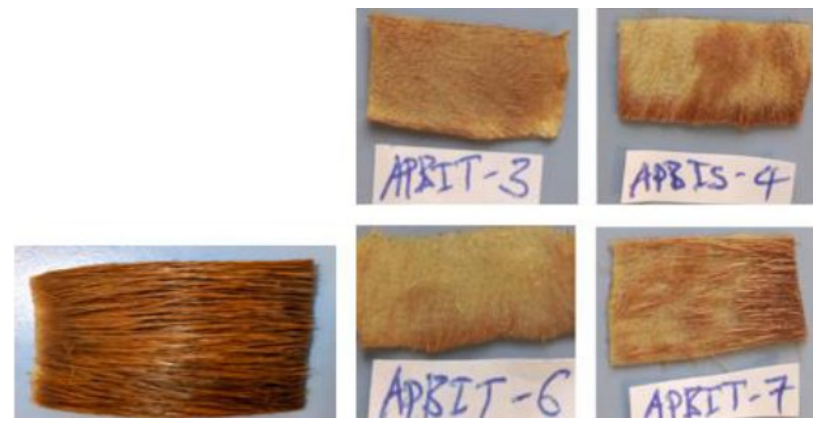

FIGURE 3 Dehairing abilities of crude enzymes extracted from isolated bacteria.

\subsection{Microscopic characterization}

The morphological features of the isolated bacteria were determined by the Gram staining technique. The APBIS4 and APBIT-3 isolates were rod-shaped Gram-negative bacteria, but APBIS-4 was non-motile and APBIT-3 was motile. APBIT-6 and APBIT-7 were motile, rod-shaped Gram-positive bacteria, as stated in Table 3.

\subsection{Enzyme tests of the isolated bacteria}

Isolates (APBIT-3, APBIS-4, APBIT-6 and APBIT-7) showed positive results for the catalase test and negative results for the urease test. APBIT-3, APBIT-6 and APBIT7 were oxidase positive, but APBIS- 4 was shown oxidase negative. APBIT-3 and APBIT-6 were shown positive results on L- Arginine dihydrolase, but APBIS-4 and APBIT-7 shown negative results as shown Table 4.

\subsection{Biochemical profile of the isolated bacteria}

As indicated in the Table 5. the isolated bacteria from the sludge disposal site at Adama Science and Technology University and sediment soil at Modjo Tannery Share Company showed different biochemical characteristics. Isolates APBIT-3, APBIS-4, APBIT-6 and APBIT-7 were showed the positive result for casein hydrolysis. APBIS4 was a carbohydrate fermenter. APBIT-3, APBIT-6 and APBIT-7 were non-carbohydrate fermenter. All four isolates were given negative results on 2-Nitro Phenyl galactopranoside, L-lysine decarboxylation and Voges Parkour's.

\subsection{Application of crude alkaline protease enzyme}

The cell-free supernatants as crude enzymes were extracted from bacteria culture by inoculating the isolated bacteria into skim milk broth medium and incubated at the appropriate temperature $\left(37^{\circ} \mathrm{C}\right.$ for $\left.48 \mathrm{~h}\right)$. The cell-free supernatant was separated from residues using a centrifuge at $10,000 \mathrm{rpm}$ for $10 \mathrm{~min}$, and then the solids were removed. The supernatant was used as a crude enzyme for washing and dehairing activities.

\subsection{Washing and Dehairing ability of crude enzyme ex- tracted from bacteria}

From this finding, all crude enzymes extracted from the isolated bacteria could remove blood. Their effectiveness to remove proteinaceous stain (blood) were APBIT6 (Bacillus carboniphilus) $\geq$ APBIT-3 (Pseudomonas putrefaciens (Shewanella putrefaciens)) $\geq$ APBIS-4 (Escherichia coli) > APBIT-7 (Lysinibacillus sphaericus); which mean that APBIT-3, APBIS-4 and APBIT-6 had almost similar efficiency for blood stain removal and APBIT-7 moderately effective at $40{ }^{\circ} \mathrm{C}$ for $20 \mathrm{~min}$ as shown Figure 2. These results indicated that the enzymes were active for destaining activity and could use as detergent additives.

The overall washing abilities of all crude enzymes were summarized in Table 6. 
TABLE 2 Morphological characteristics of 24 hours colony on blood agar.

\begin{tabular}{|c|c|c|c|c|c|c|}
\hline Selected colonies & Type & Shape & Texture & Elevation & Margin & Pigmentation \\
\hline APBIT-3 & Mucoid & Flat & Smooth & Convex & Entire & Greenish \\
\hline APBIS-4 & Mucoid & Circular & Smooth & Convex & Entire & White \\
\hline APBIT-6 & Dry & Circular & Rough & Pulvinate & Entire & Deep White \\
\hline APBIT-7 & Mucoid & Circular & Smooth & Flat & Entire & Gray \\
\hline
\end{tabular}

TABLE 3 Microscopic and motility results of isolated bacteria.

\begin{tabular}{lll}
\hline Selected Colonies & Gram Staining & Motility \\
\hline APBIT-3 & Gram negative, Rod & Motile \\
APBIS-4 & Gram Negative, Rod & Non-motile \\
APBIT-6 & Gram positive, Rod & Motile \\
APBIT-7 & Gram positive, Rod & Motile \\
\hline
\end{tabular}

TABLE 4 Microscopic and motility results of isolated bacteria.

\begin{tabular}{lllll}
\hline Enzyme tests & APBIT-3 & APBIS-4 & APBIT-6 & APBIT-7 \\
\hline Catalase & + & + & + & + \\
Oxidase & + & - & + & + \\
URE (Urea hydrolysis) & - & - & - & - \\
$\begin{array}{l}\text { ADH (L- Arginine } \\
\text { dihydrolase) }\end{array}$ & + & - & + & - \\
\hline$+=$ Positive, _ Negative & & & &
\end{tabular}

\subsection{Dehairing ability of crude enzyme extracted from bacteria}

All crude enzymes obtained from four isolated bacteria could remove hair. The effectiveness of the crude enzyme extracts obtained from APBIT-3 (P. putrefaciens (S. putrefaciens)) and APBIT-6 (B. carboniphilus) to remove hairs from skin were almost similar efficiencies. However, the quality (softness) of skin treated with crude enzyme obtained from APBIT-6 (B. carboniphilus) was most effective. Figure 3 showed that the crude enzyme obtained from E. coli was moderately effective and crude enzyme extract from $L$. sphaericus was less effective at $40{ }^{\circ} \mathrm{C}$ within $48 \mathrm{~h}$.

The overall dehairing ability of all crude enzymes was summarized in Table 7.

\subsection{Discussion}

In this study, potentially alkaline protease-producing bacteria were isolated from the sludge disposal site at Adama Science and Technology University (ASTU) campus and sediment soil in Modjo Tannery Share Company (MTSC). From a total of 16 bacterial isolates obtained from sludge disposal site and tannery waste, four isolates showed promising proteolytic activity on skim milk agar. Protease-producing bacteria isolated from the study area were identified and their dehairing and destaining abilities were assessed. All the isolated bacteria could hydrolysis casein protein on skim milk agar, which indicates that all bacteria could produce the enzyme protease that degraded casein protein. This impels that sludge disposal sites and soil sediments around tannery waste are
TABLE 5 Biochemical characteristics of isolated bacteria.

\begin{tabular}{|c|c|c|c|c|c|}
\hline No & Biochemical tests & APBIS-4 & APBIT-3 & APBIT-6 & APBIT-7 \\
\hline 1 & $\begin{array}{l}\text { O-NPG (O-Nitro } \\
\text { Phenyl } \\
\text { Galactopranoside) }\end{array}$ & - & - & - & - \\
\hline 2 & $\begin{array}{l}\text { LDC (L- Lysine } \\
\text { decarboxylation) }\end{array}$ & - & - & - & - \\
\hline 3 & $\begin{array}{l}\text { ODC (L-Omithine } \\
\text { decarboxylation) }\end{array}$ & - & + & - & - \\
\hline 4 & $\begin{array}{l}\text { CIT (Citrate } \\
\text { utilization) }\end{array}$ & - & - & - & + \\
\hline 5 & $\mathrm{H} 2 \mathrm{~S}$ production & - & + & - & - \\
\hline 6 & No3 reduction & + & - & - & - \\
\hline 7 & $\begin{array}{l}\text { TDA (L-Tryptophan } \\
\text { deamination) }\end{array}$ & + & - & - & - \\
\hline 8 & $\begin{array}{l}\text { IND (Indole } \\
\text { production) }\end{array}$ & + & - & - & - \\
\hline 9 & $\begin{array}{l}\text { VP (Voges } \\
\text { parkour's) }\end{array}$ & - & - & - & - \\
\hline 10 & $\begin{array}{l}\text { GEL (Gelatin } \\
\text { hydrolysis) }\end{array}$ & - & + & + & - \\
\hline 11 & Casein hydrolysis & + & + & + & + \\
\hline 12 & $\begin{array}{l}\text { GLU (Glucose } \\
\text { fermentation) }\end{array}$ & + & - & - & - \\
\hline 13 & $\begin{array}{l}\text { Lactose } \\
\text { fermentation }\end{array}$ & + & - & - & - \\
\hline 14 & MAN (D- Mannitol) & + & - & - & - \\
\hline 15 & INO (Inositol) & + & - & - & - \\
\hline 16 & SOR (D- Sorbitol) & + & - & - & - \\
\hline 17 & RHA (L- Rhamnose) & + & - & - & - \\
\hline 18 & SAC (D- Sucrose) & + & - & - & - \\
\hline 19 & MEL (D- Maltose) & + & - & - & - \\
\hline 20 & $\begin{array}{l}\text { ESC (Escuilin ferric } \\
\text { citrate) }\end{array}$ & + & + & + & - \\
\hline 21 & ARA (L- Arabinose) & + & _ & _ & _ \\
\hline
\end{tabular}

good protease-producing bacteria sources. The potential of sludge disposal site soils in ASTU Campus and sediment at Modjo Tannery Share Company waste was not reported as a source of alkaline protease-producing bacteria so far.

Based on Bergey's Manual of Determinative Bacteriology 7ed and ABIS version 12 software isolate coded as APBIS-4 was E. coli; APBIT-3 was $P$. putrefaciens; APBIT-6 was B. carboniphilus; and APBIT-7 was $L$. sphaericus. The isolated bacteria were found in three genera groups, namely Bacillus spp. (B. carboniphilus and $L$. 
TABLE 6 Washing abilities of crude enzymes obtained from bacterial isolates.

\begin{tabular}{llll}
\hline Codes & $\begin{array}{l}\text { Isolated bacteria } \\
\text { species }\end{array}$ & $\begin{array}{l}\text { Site of } \\
\text { isolation }\end{array}$ & Washing ability \\
\hline APBIT-3 & P. putrefaciens & MTSC & Excellent \\
APBIS-4 & E. coli & $\begin{array}{l}\text { ASTU } \\
\text { campus }\end{array}$ & Excellent \\
APBIT-6 & B. carboniphilus & MTSC & Excellent \\
APBIT-7 & L. sphaericus & MTSC & Very good \\
\hline
\end{tabular}

Excellent $=$ blood stain completely removed, Very Good $=$ blood stain not completely removed

TABLE 7 Isolated bacteria and dehairing abilities of their respective crude enzymes.

\begin{tabular}{lllll}
\hline Codes & $\begin{array}{l}\text { Isolated bacteria } \\
\text { species }\end{array}$ & $\begin{array}{l}\text { Sites of } \\
\text { isolation }\end{array}$ & $\begin{array}{l}\text { Dehairing } \\
\text { ability }\end{array}$ & $\begin{array}{l}\text { Softness of } \\
\text { skin }\end{array}$ \\
\hline APBIT-3 & P. putrefaciens & MTSC & Excellent & Very good \\
APBIS-4 & E. coli & $\begin{array}{l}\text { ASTU } \\
\text { campus }\end{array}$ & Very good & Excellent \\
APBIT-6 & B. carboniphilus & MTSC & Excellent & Excellent \\
APBIT-7 & L. sphaericus & MTSC & Good & Very good \\
\hline
\end{tabular}

Excellent $=75-100 \%$ hair removed and soften the skin, Very Good $=$ $50-74 \%$ hair removed and soften the skin, Good= less than $50 \%$ hair removed

sphaericus) and others were Enterobacteriaceae sp. (E. coli) and Pseudomonas sp. (P. putrefaciens (S. putrefaciens).

B. carboniphilus is a Gram-positive, rod-shaped bacteria, obligate aerobes, or facultative anaerobes (Mohammed et al. 2016). Under stressful environmental conditions, these bacteria can produce endospores and remain a dormant state for long periods. L. sphaericus (Tallur et al. 2016) is a Gram-positive, mesophilic, rod-shaped bacterium commonly found in soil. It is spore-forming bacteria, tolerant to high temperatures, chemicals, and ultraviolet light, and can remain viable for long periods in soil. L. sphaericus' ability of the pure bacterial cultures to produce extracellular protease enzyme was carried out by growing the cultures on skim milk agar. L. sphaericus is a well-known bacterium used in the biological control of mosquitoes. It is of particular interest to the WHO due to the larvicidal effect of some strains against two mosquito's genera (Culex and Anopheles) (Wirth et al. 2014). Additionally, L. sphaericus had the ability to tolerate and reduces heavy metals; hence is commercially important in leather and detergent industries (Tallur et al. 2016). This bacteria species was effective in detergent and can be used as a detergent additive.

P. putrefaciens (S. putrefaciens) (Bayoumi et al. 2012) is Gram negative, facultative anaerobic, non- lactose fermenter, on blood agar plate, the colony is typically convex and large, with a brown pigment, and cause "greening" of the agar around the colonies. Shewanella species had the ability to reduce mercury, iron, uranium, and plutonium metabolically. These heavy metals, especially mercury, were released from leather industries and are toxic to the organisms living in water bodies (Bayoumi et al. 2012). These bacteria were isolated from the sediment soil from the leather industry and had the ability to remove hair from the hide and had excellent ability to remove proteinaceous (blood) stain from white cloth.

E. coli, according to (Fu et al. 2003) is Gram negative, rod, and mesophilic, facultative anaerobic and lactose fermenting bacteria. E. coli produces alkaline protease enzyme into alkaline culture media (Skim milk agar). This protease enzyme helps to hydrolysis protein (casein) which is found in the culture media (Skim milk agar) as their carbon and nitrogen source (Fu et al. 2003). they reported that the protease enzyme released by $E$. coli is commercially important, mostly in laundry detergent to remove pretentious stains. Similarly, from the current findings, E. coli had great activity in blood stain removal. In dehairing activity, E. coli had shown remarkable activity and the softness of skin was promising. These results were encouraging as the isolated bacterial cultures had novel applications and also gave an emerging view of the bacterial diversity in the study area since, there was no/ not much information available on bacterial diversity from sediment released from Modjo Tannery Share Company and sludge disposal site at ASTU.

\section{Conclusions}

It can be concluded that the soils of sludge disposal sites and sediments around tannery wastes could be good sources for isolating alkaline protease-producing bacteria. The alkaline proteases obtained from bacterial species adapted in the sludge disposal sites and tannery sediments have the potential application in detergent and diaries industries. From four bacteria isolates having high proteolytic activity, two isolates were Bacillus species called $B$. carboniphilus and $L$. sphaericus. The remaining isolates were Enterobacteriaceae sp. (E. coli) and Pseudomonas sp. (P. putrefaciens (S. putrefaciens). Alkaline protease produced from Bacillus sp. APBIT-6 (B. carboniphilus) in the present study had shown high potential in removing hair from animal skin with improved quality and removing proteinacious stain (blood). Finally, alkaline protease produced from Bacillus sp. APBIT-6 (B. carboniphilus) was selected as the most potent bacteria species due to potential industrial application for both washing ability in detergent and softness and dehairing purpose in leather processing.

\section{Acknowledgments}

The authors acknowledge Adama Science and Technology University for financial support and Oromia Public Health Research Capacity Building Quality Assurance Laboratory (OPHRCBQAL) for providing experimental facilities to carry out this research work. 


\section{Authors' contributions}

YAL carried out the laboratory work, data analysis and first draft manuscript. TGB advised, and further manuscript write up improvement. AZC advised and carried out the laboratory work. FBL advised and laboratory facility fasilitator. All authors read and approved the final version of the manuscript.

\section{Competing interests}

The author declare that they have no competing interest.

\section{References}

Aftab S, Ahmed S, Saeed S, Rasool SA. 2006. Screening, isolation and characterization of alkaline protease producing bacteria from soil. Pak J Biol Sci. 9(11):2122-2126. doi:10.3923/pjbs.2006.2122.2126.

Bayoumi RA, Atta HM, El-Sehrawy MH. 2012. Bioremediation of khormah slaughter house wastes by production of thermoalkalistable lipase for application in leather industries. Life Sci J. 9(4):1324-1335.

Dudhgara PR, Sunil B, Anjana G. 2015. Hide dehairing and laundry detergent compatibility testing of thermostable and solvents tolerant alkaline protease from hot spring isolate bacillus cohniiU3. OnLine J Biol Sci. 15(3):152-161. doi:10.3844/ojbsci.2015.152.161.

Fu Z, Hamid SBA, Razak CNA, Basri M, Bakar Salleh A, Rahman RNZA. 2003. Secretory expression in Escherichia coli and single-step purification of a heat-stable alkaline protease. Protein Expression and Purification 28(1):63-68. doi:10.1016/S10465928(02)00637-X.

Gessesse A, Mulaa F, Lyantagaye S, L NW, Mattiasson B, Pandey A. 2011. ndustrial enzymes for sustainable bio-economy: Large scale production and application in industry, environment, and agriculture in eastern africa.

Gupta R, Beg Q, Lorenz P. 2002. Bacterial alkaline proteases: Molecular approaches and industrial applications. Appl Microbiol Biotechnol. 59(1):15-32. doi:10.1007/s00253-002-0975-y.

Kocher GS, Mishra S. 2010. Immobilization of Bacillus circulans MTCC 7906 for enhanced production of alkaline protease under batch and packed bed fermentation conditions. Internet J Microbiol. 7(2). doi:10.5580/2599.

Mohammed I, Hampton SE, Ashall L, Hildebrandt ER, Kutlik RA, Manandhar SP, Floyd BJ, Smith HE, Dozier JK, Distefano MD, Schmidt WK, Dore TM. 2016. 8-Hydroxyquinoline-based inhibitors of the Rce1 protease disrupt Ras membrane localization in human cells. Bioorg Med Chem. 24(2):160-178. doi:10.1016/j.bmc.2015.11.043.
Murray CW, Callaghan O, Chessari G, Cleasby A, Congreve M, Frederickson M, Hartshorn MJ, McMenamin R, Patel S, Wallis N. 2007. Application of fragment screening by X-ray crystallography to $\beta$-secretase. J Med Chem. 50(6):1116-1123. doi:10.1021/jm0611962.

Nikolic M, Terzic-Vidojevic A, Jovcic B, Begovic J, Golic N, Topisirovic L. 2008. Characterization of lactic acid bacteria isolated from Bukuljac, a homemade goat's milk cheese. Int J Food Microbiol. 122(1-2):162-170. doi:10.1016/j.ijfoodmicro.2007.11.075.

Sneath PH. 1986. Endospore-forming gram-positive rods and cocci., booktitle = Bergey's manual of systematic bacteriology. p. 1104-1207.

Tallur PN, Sajjan DB, Mulla SI, Talwar MP, Pragasam A, Nayak VM, Ninnekar HZ, Bhat SS. 2016. Characterization of antibiotic resistant and enzyme producing bacterial strains isolated from the Arabian Sea. 3 Biotech. 6(1):1-11. doi:10.1007/s13205-015-0332-3.

Wirth MC, Berry C, Walton WE, Federici BA. 2014. Mtx toxins from Lysinibacillus sphaericus enhance mosquitocidal cry-toxin activity and suppress cryresistance in Culex quinquefasciatus. J Invertebr Pathol. 115(1):62-67. doi:10.1016/j.jip.2013.10.003. 